\title{
Structure and transcriptional regulation of the gene encoding pyruvate formate-lyase of a ruminal bacterium, Streptococcus bovis
}

\author{
Narito Asanuma, Miwa Iwamoto and Tsuneo Hino
}

Author for correspondence: Tsuneo Hino. Tel: +8144934 7825. Fax: +81 449347825.
e-mail: hino@isc.meiji.ac.jp

Department of Agriculture, Meiji University,

Higashimita, Tama-ku, Kawasaki 214-8571, Japan

\begin{abstract}
The gene (pfl) encoding pyruvate formate-lyase (Pfl) from Streptococcus bovis was sequenced. The deduced amino acid sequence of Pfl was similar to Streptococcus mutans Pfl, and included the conserved regions necessary for free-radical formation and a catalytic site. The Pfl of S. bovis appeared to be a free-radical-containing enzyme because of its dioxygen sensitivity and its amino acid sequence similarity with the Escherichia coli enzyme. The pfl mRNA of $S$. bovis was approximately $2.3 \mathrm{~kb}$ and was transcribed in a monocistronic fashion. When cells were grown in batch culture at pH 6.9, the level of pfI transcript increased as the growth phase changed from exponential growth to stationary phase. This result was in constrast to the previous observation that the level of lactate dehydrogenase (Ldh) mRNA decreased during the later stages of growth. Continuous culture experiments conducted at pH 6.9 under glucose-limited and ammonia-limited conditions revealed that pfI mRNA was decreased by an excess supply of glucose, as well as by a high growth rate. On the contrary, Idh mRNA increased when excess glucose was supplied and the growth rate was high. The amount of pfl mRNA in cells was lower at pH 4.5 than pH 6.9, whereas the level of Idh mRNA was higher at pH 4.5. This result was consistent with the amounts of PfI and Ldh in cells and the proportion of formate and lactate produced. These results support the hypothesis that $S$. bovis regulates PfI and Ldh synthesis at the transcriptional level in response to growth conditions.
\end{abstract}

Keywords: Streptococcus bovis, pyruvate formate-lyase, rumen bacteria, $p f$ gene, transcription

\section{INTRODUCTION}

Streptococcus bovis often predominates in the rumen when high-starch diets are fed (Marounek \& Bartos, 1987; Hungate, 1966) and produces lactate as the major fermentation product when excess energy source is present and the growth rate is high (Asanuma et al., 1997). The increased lactate production brings about a drop in ruminal pH. S. bovis is acid resistant compared with other main ruminal bacteria, and is able to grow at pH 4.5 (Asanuma \& Hino, 1997). The percentage of lactate in the fermentation products of $S$. bovis also

Abbreviations: $\mathrm{D}$, dilution rate; Ldh, lactate dehydrogenase; Pfl, pyruvate formate-lyase

The GenBank/EMBLDDBJ accession number for the $S$. bovis pfl sequence reported in this paper is AB014686. increases when the environmental $\mathrm{pH}$ is low (Russell \& Hino, 1985; Asanuma \& Hino, 1997). Thus, S. bovis continues to produce lactate, and potentially contributes to the progress of rumen acidosis (Russell \& Hino, 1985).

The increase in lactate production at low $\mathrm{pH}$ can be explained by the fact that $S$. bovis allows its intracellular $\mathrm{pH}$ to decrease to around $\mathrm{pH} 5 \cdot 5$ when the extracellular pH decreases to $4 \cdot 7$ (Russell \& Hino, 1985; Russell, 1991); the $\mathrm{pH}$ optimum of its lactate dehydrogenase (Ldh) is pH 5.5 (Russell \& Hino, 1985; Asanuma \& Hino, 1997). In addition, S. bovis increases the synthesis of Ldh in response to low pH (Asanuma et al., 1997; Asanuma \& Hino, 1997). The enhanced lactate production by the excess supply of energy source is in part caused by the increase in the intracellular concentration of fructose-1,6-diphosphate which enhances Ldh activity (Russell \& Hino, 1985). 
The percentage of lactate in fermentation products depends on the partition of the flow from pyruvate, which is a branching point in the pathways of sugar fermentation. In S. bovis, pyruvate is either converted to lactate by Ldh or to acetyl-CoA and formate by pyruvate formate-lyase ( $\mathrm{Pfl})$. Therefore, it is also important to understand how $\mathrm{Pfl}$ activity is affected by $\mathrm{pH}$ and energy supply. Allosteric regulation of $\mathrm{Pfl}$ by triose phosphate is important in Streptococcus mutans (Thakahashi et al., 1982), Streptococcus lactis (Fordyce et al., 1984), Streptococcus cremoris (Thomas et al., 1980), and S. bovis (unpublished observation). However, it may also be possible that the synthesis of $\mathrm{Pfl}$ is regulated in response to changes in culture conditions.

Formate production in the rumen implies that formate is used as a substrate for methane production. Since methane may contribute to the greenhouse effect, it is important to control formate production. In the main ruminal bacteria which produce formate, it appears to be formed by the Pfl reaction (Asanuma et al., 1998). However, no reports on Pfl activity of ruminal bacteria are currently available.

So far, Pfl has been investigated for several bacteria such as Escherichia coli, Clostridia (Thauer et al., 1972; Wood \& Jungermann, 1972), Streptococcus faecalis (Lindmark et al., 1969), S. mutans (Thakahashi et al., 1982) and Micrococcus lactilyticus (McCormick et al., $1962 \mathrm{a}, \mathrm{b})$. Of these bacteria, the Pfl of E. coli has been studied in detail (Knappe \& Blaschkowski, 1975 ; Kessler \& Knappe, 1996). E. coli Pfl, which loses activity in contact with $\mathrm{O}_{2}$, functions under anaerobic conditions. In E. coli, Pfl consisting of two identical $85 \mathrm{kD}$ a subunits is synthesized as the inactive, nonradical form $\left(\mathrm{E}_{\mathrm{i}}\right)$, and is post-translationally converted to the active, radical form $\left(E_{a}\right)$. The activating enzyme, which itself must be activated for the activation of $\mathrm{Pfl}$, is activated by reduction through reduced flavodoxin. The active form of the activating enzyme converts $E_{i}$ to $E_{a}$ by donating an electron. $E_{a}$ possesses an organic free radical at the active site, on the $\alpha$-carbon of Gly ${ }^{734}$, and the mechanism of its action has been proposed to be a homolytic process with the participation of the organic free radical (Urking et al., 1989). The reversible formation of the active-site radical is tightly regulated by the Pfl-activating enzyme and the deactivating enzyme catalysing the conversion of $E_{\mathrm{a}}$ to $\mathrm{E}_{\mathrm{i}}$, both of which are sensitive to the metabolic status of the micro-organism (Wong et al., 1993).

The objective of this study was to clarify how the synthesis of $\mathrm{Pfl}$ in S. bovis is regulated, especially at the transcriptional level. For this purpose, we analysed the nucleotide sequence of the gene encoding Pfl $(p f l)$ with the primer extention analysis. In addition, we examined the effect of culture conditions on the level of $p f l$ mRNA, together with the effect on the $l d h$ mRNA level.

\section{METHODS}

Bacterial strain and growth conditions. The source of $S$. bovis JB1 was as described previously (Asanuma \& Hino, 1997). Batch culture of $S$. bovis was carried out in $120 \mathrm{ml}$ serum vials as described previously (Asanuma \& Hino, 1997). The medium for batch culture contained $\left(\mathrm{g} \mathrm{l}^{-1}\right): \mathrm{K}_{2} \mathrm{HPO}_{4}, 0.45$; $\mathrm{KH}_{2} \mathrm{PO}_{4}, 0.45 ;\left(\mathrm{NH}_{4}\right)_{2} \mathrm{SO}_{4}, 0.9 ; \mathrm{NaCl}, 0.9 ; \mathrm{CaCl}_{2} .2 \mathrm{H}_{2} \mathrm{O}, 0.12$; $\mathrm{MgSO}_{4} \cdot 7 \mathrm{H}_{2} \mathrm{O}, 0.19$; glucose, 3 ; Trypticase (BBL), 1.0 ; yeast extract (Difco), $1.0 ;$ cysteine- $\mathrm{HCl}, 0.6$. The medium was adjusted to $\mathrm{pH} 6.9$ with $8 \%(\mathrm{w} / \mathrm{v}) \mathrm{Na}_{2} \mathrm{CO}_{3}$. Incubation was performed in triplicate, maintaining the $\mathrm{pH}$ apporoximately constant by adding anaerobic $\mathrm{Na}_{2} \mathrm{CO}_{3}$ (Hino et al., 1992). Cell growth was estimated by measuring the $\mathrm{OD}_{600}$.

Apparatus and general procedures for continuous culture were as described previously (Hino \& Hamano, 1993; Hino et al., 1993; Hino \& Miwa, 1996). The apparatus consisted of four sets of a 51 reservoir bottle, a peristaltic pump, an overflow-type fermenter with a capacity of $500 \mathrm{ml}$ and a 51 drainage bottle. The glucose-limited medium contained $\left(\mathrm{g} \mathrm{l}^{-1}\right): \mathrm{K}_{2} \mathrm{HPO}_{4}, 0 \cdot 45 ; \mathrm{KH}_{2} \mathrm{PO}_{4}, 0 \cdot 45 ;\left(\mathrm{NH}_{4}\right)_{2} \mathrm{SO}_{4}, 1 \cdot 8 ; \mathrm{NaCl}$, $0 \cdot 9 ; \mathrm{CaCl}_{2} .2 \mathrm{H}_{2} \mathrm{O}, 0 \cdot 12 ; \mathrm{MgSO}_{4} .7 \mathrm{H}_{2} \mathrm{O}, 0 \cdot 19 ;$ glucose, $3 \cdot 0$; Trypticase (BBL) 0.5 ; yeast extract (Difco), $0.5 ;$ cysteine. $\mathrm{HCl}$, 0.6 . In the ammonia-limited medium, glucose was increased to $5 \mathrm{~g} \mathrm{l}^{-1}$ and $\left(\mathrm{NH}_{4}\right)_{2} \mathrm{SO}_{4}$ was decreased to $0 \cdot 1 \mathrm{~g} \mathrm{l}^{-1}$. Continuous culture was performed in duplicate fermenters at $39^{\circ} \mathrm{C}$ under a stream of $\mathrm{CO}_{2}+\mathrm{N}_{2}(1: 9)$ for $4 \mathrm{~d}$, repeating the same experiment twice. The dilution rate (D) was set at 0.1 or $0.6 \mathrm{~h}^{-1}$ and the $\mathrm{pH}$ was maintained at $\mathrm{pH} 6.9$ or 4.5 .

Samples for the determination of fermentation products and bacterial cells for the measurement of the enzyme content and Northern-blot analysis were taken from the fermenters on the last day of the culture. Unless otherwise stated, the cultures $(500 \mathrm{ml})$ were immediately cooled in an ice bath and cells were collected by centrifugation $\left(20000 \mathrm{~g}, 10 \mathrm{~min}, 2^{\circ} \mathrm{C}\right)$.

Determination of fermentation products, glucose, ammonia and cellular nitrogen. Organic acids were analysed by HPLC (Hino et al., 1994) and glucose was determined as described previously (Asanuma \& Hino, 1997). Ammonia was collected by the Conway's micro-diffusion method (Conway \& Byrne, 1933) and assayed by the indophenol method (Chaney \& Marbach, 1962). Cellular nitrogen was determined by digesting the cells by the Kjeldahl method, followed by the quantification of ammonia by the indophenol method.

Assay for Ldh and Pfl activity. Cell-free extracts of S. bovis for the assay of Ldh and Pfl activity were prepared as described previously (Asanuma \& Hino, 1997), except that all the treatments were performed in an anaerobic glove box because no Pfl activity was detected when extracted in air. From the extracts, Pfl and Pfl-activating enzyme were isolated by the combination of protamine sulfate and ammonium sulfate precipitation, and then by two successive column chromatographies essentially according to the method of Knappe \& Blaschkowski (1975). Flavodoxin was isolated by the method of Vetter \& Knappe (1971) with a minor modification. The isolation of spinach chloroplast fragments and the estimation of chlorophyll content were carried out according to the method of Whatlay \& Arnon (1963). The activation of Pfl was performed essentially by the method of Knappe \& Blaschkowski (1975) using a device for anaerobic treatments. The details of the device will be reported elsewhere. The activity of Ldh (Russell \& Hino, 1985; Asanuma \& Hino, 1997) and Pfl (Knappe \& Blaschkowski, 1975) was estimated by measuring the rate of $\mathrm{NADH}$ oxidation at $A_{340}$. The reaction mixture for the Pfl assay contained $20 \mathrm{mM}$ sodium pyruvate, $0.08 \mathrm{mM}$ CoA, $1 \mathrm{mM}$ NAD, $6 \mathrm{mM}$ sodium malate, $2 \mathrm{mM}$ DTT, $1.4 \mathrm{U}$ citrate synthase $\mathrm{ml}^{-1}, 14 \mathrm{U}$ malate dehydrogenase $\mathrm{ml}^{-1}$ and cell

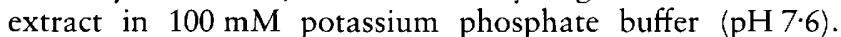
Again, the details of the determination of Pfl activity will be reported elsewhere. One unit of activity of each enzyme was 
(a)

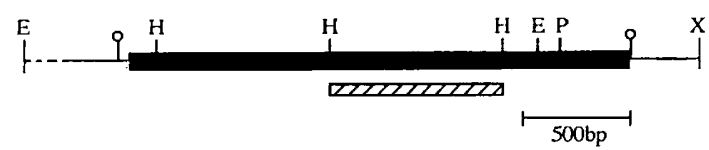

(b)

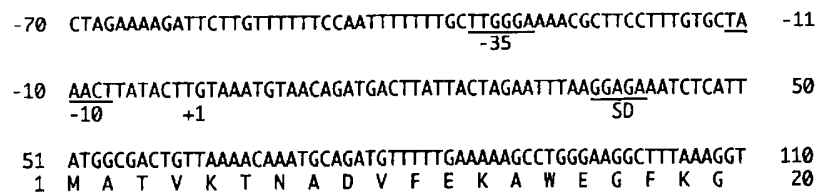

$\begin{array}{rl}2331 & \text { GTTCTTTCAATGGATGATGTTGCTGAAACTGTTGCTGCTAAATAATAAATATCGAAAAAG } \\ 761 & 2390 \\ 774\end{array}$

2391 ACTTTGTCAGTTGACAGAGTCTIIIITGTCCTTAAAATAGAGCTATGAAAATCAAACAA 2450

Fig. 1. Restriction map of the genomic DNA surrounding the pfl gene and the nucleotide sequence of the pfl operon with the deduced amino acid sequence. (a) Restriction map of genomic DNA. The pfl gene is shown as a black box. The putative transcriptional start site and the termination site are shown as white circles. The DNA fragment used as a probe is shown as a striped box. Only relevant restriction sites are shown: E, EcoRl; $H$, HindIII; P, Pstl; X, Xbal. (b) Nucleotide sequence of parts of the $p f l$ gene. Position +1 refers to the $p f l$ transcriptional start site. The arrows downstream from the pfl gene indicate an inverted repeat sequence. Putative Shine-Dalgarno (SD) sequence, and -35 and -10 regions are also shown.

defined as $1 \mu \mathrm{mol} \mathrm{NADH}$ oxidized $\min ^{-1}$ and the activity was expressed per $\mu$ g cellular nitrogen, which was parallel with cell mass $\left(\mathrm{OD}_{600}\right.$ value and the dry weight of cells). The activity expressed as such represents the amount of enzyme per cell mass, because sonication was repeatedly performed until approximately $95 \%$ of cells were disrupted as previously described (Asanuma \& Hino, 1997).

Extraction of genomic DNA and sequencing of the pfl gene. Genomic DNA was isolated from $S$. bovis as described previously (Asanuma \& Hino, 1997). The DNA was digested and ligated with the enzymes shown in Fig. 1 from Takara Shuzo under conditions recommended by the supplier.

The nucleotide sequence was determined on both strands by using an Applied Biosystems PRISM Terminator cycle sequencing kit and an Applied Biosystems 3735 sequencer. The sequence data were evaluated on the basis of sequence homology to $p f l$ genes in GenBank using BLASTN and BLASTP (NCBI), and analysed using GENETYX-MAC version 8.0 (Software Development).

PCR amplification. The sequences of the $p f l$ genes from $E$. coli, Clostridium pasteurianum and $S$. mutans were used to design degenerate oligonucleotide primers for a PCR reaction. A 17 mer oligonucleotide (5' ACHGGWCTBCCAGATGC 3', +549 to +565$)$ and a 21 mer oligonucleotide $\left(5^{\prime}\right.$ ATHGGTTTWACWKTMGCATAT $33^{\prime},+1670$ to +1690$)$ were synthesized with a DNA synthesizer (model 380A, Applied Biosystems) and a 1142 bp fragment from genomic DNA of $S$. bovis was amplified. Subsequently, inverse PCR was carried out on EcoRI-digested and religated genomic DNA to clone the upstream region of the $p f l$ gene. Inverse PCR was carried out again with Xbal-digested genomic DNA to clone the downstream region of the $p f l$ gene. PCR amplification was conducted with Takara LA Taq polymerase. The PCR products were purified with a QIAquick PCR purification kit (Qiagen) and directly sequenced.

Primer extension analysis. Primer extension analysis was carried out with approximately $10 \mu \mathrm{g}$ total RNA and a IRD41labelled primer, pfl-EX (5' CTTTTTCTTTCCAGTCAGTACCTTTA 3', from +104 to +129 ), with MMLV Reverse Transcriptase RNase H Minus (Toyobo). Products of the primer extension reaction were separated on sequencing gels alongside sequence reactions performed on the corresponding PCR product including the upstream region of the $p f l$ gene using pfl-EX. Sequencing reactions were carried out with a Sequi Therm Long-Read Cycle Sequencing kit (Aloka) and a Li-cor DNA sequencer (Aloka).

Northern-blot analysis of $/ \boldsymbol{d} \boldsymbol{h}$ and $\mathbf{p f I}$ mRNAs. The cell samples for Northern-blot analysis were centrifuged $(20000 \mathrm{~g}, 10 \mathrm{~min}$, $2{ }^{\circ} \mathrm{C}$ ) and the pellet was immediately frozen by immersing in cold ethanol $\left(-80^{\circ} \mathrm{C}\right)$ and stored at $-80^{\circ} \mathrm{C}$. Total RNA was extracted from $S$. bovis cells as described previously (Asanuma et al., 1997). Exactly $10 \mu \mathrm{g}$ RNA was separated in a $1.0 \%$ $(\mathrm{w} / \mathrm{v})$ agarose $/ 0.6 \%(\mathrm{w} / \mathrm{v})$ formaldehyde gel. Blotting, hybridization, and washing were carried out as described previously (Asanuma et al., 1997). The S. bovis ldh-specific hybridization probe was described in a previous paper (Asanuma et al., 1997). Similarly, the S. bovis $p f l$-specific probe was designed as shown in Fig. 1. The amounts of $l d h$ and $p f l$ mRNA in $10 \mu \mathrm{g}$ total RNA were estimated from peak area and intensity by using a Fluor-S Multi Imager (Bio-Rad). To make a standard curve for each mRNA, graded amounts of an identical RNA sample were subjected to Northern-blot analysis. The standard curve of each mRNA was not a straight line but a hyperbolic curve. The relative amounts of each mRNA in the samples were determined from the standard curves.

Evaluation of data. Data were evaluated by a Tukey's test at $P<0.05$ (Snedecor \& Cochran, 1967).

\section{RESULTS AND DISCUSSION}

\section{Nucleotide sequence of the $S$. bovis pfl gene}

A 1142 bp segment of the $p f l$ gene $(+549$ to +1690$)$ was amplified from genomic DNA by PCR with degenerate primers. This region showed high levels of homology to the $p f l$ genes of other bacteria (BLAST search). To obtain the segment upstream of this region, inverse PCR was performed on EcoRI-digested and religated genomic DNA by using primers on the $5^{\prime}$ and $3^{\prime}$ ends of the $1142 \mathrm{bp}$ fragment. The inverse PCR product was approximately $2.6 \mathrm{~kb}$ long. Sequence analysis showed that this fragment contained the $5^{\prime}$ end of the $p f l$ gene. Then, inverse PCR was carried out on XbaI-digested DNA by using two primers designed on the $5^{\prime}$ terminal sequence of the $p f l$ gene and the $3^{\prime}$ terminal sequence of the $2 \cdot 6 \mathrm{~kb}$ fragment. This inverse PCR product was approximately $3.0 \mathrm{~kb}$ and contained the $3^{\prime}$ end of the $p f l$ gene. The $S$. bovis pfl operon was found to consist of $2325 \mathrm{bp}$, beginning with ATG and terminating with a TAA codon, and encodes a 774 amino acid Pfl protein with a deduced molecular mass of $87513 \mathrm{Da}$.

The deduced amino acid sequence of $S$. bovis $\mathrm{Pfl}$ showed more than $40 \%$ similarity to those of E. coli, C. 
(a)

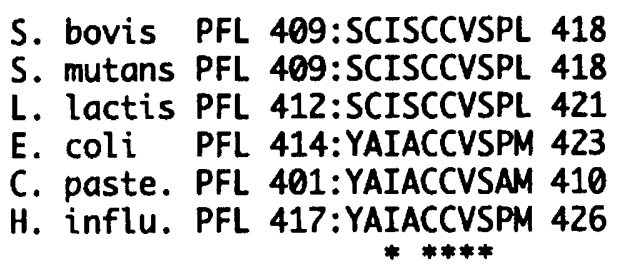

(b)

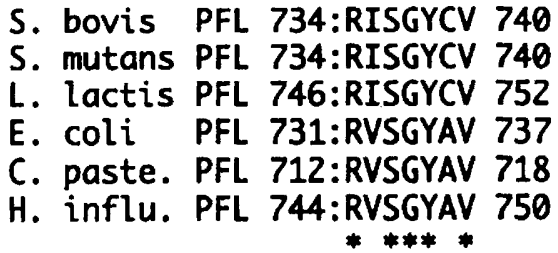

Fig. 2. Alignment of Pfl proteins at the catalytic site (a) and the radical-forming site (b). The sequence of Streptococcus bovis $\mathrm{PfI}$ is aligned with all Pfl entries available in the databases by using the GENETYX-MAC 8.0. Asterisks in the consensus line represent identical amino acid residues.

pasteurianum and Haemophilus influenzae Pfls. The similarity was especially high to the Pfls of $S$. mutans $(90 \%)$ (Yamamoto et al., 1996) and Lactococcus lactis $(80 \%)$ (Arnau et al., 1997). The S. bovis Pfl included the conserved regions necessary for free-radical formation and a catalytic site (Fig. 2) (Knappe et al., 1984; Wagner et al., 1992; Parast et al., 1995). The Gly ${ }^{734}$ residue, which is involved in free-radical formation in the active form of the enzyme in E. coli (Wagner et al., 1992), was conserved at residue 737 in $S$. bovis, flanked by Ser ${ }^{736}$ and $\mathrm{Tyr}^{738}$. $\mathrm{Cys}^{418}$ and $\mathrm{Cys}^{419}$, which play an auxiliary role in the $\mathrm{C}-\mathrm{C}$ bond cleavage of pyruvate and catalyses hydrogen exchange of the glycyl radical of the enzyme in E. coli (Parast et al., 1995), were conserved in S. bovis Pfl at residues 413 and 414 . These regions are conserved in all Pfl proteins characterized to date (Fig. 2).

S. bovis $\mathrm{Pfl}$ appeared to be a free-radical-containing enzyme because of its dioxygen sensitivity and its similarity to the E. coli enzyme. It is probable that $S$. bovis $\mathrm{Pfl}$ is activated by a mechanism similar to that of $E$. coli, because $S$. bovis $\mathrm{Pfl}$ was activated by the activating system for E. coli $\mathrm{Pfl}$ with S-adenosyl methionine, flavodoxin and chloroplasts (Knappe et al., 1984), in which Pfl prepared from E. coli was replaced by Pfl from S. bovis (unpublished results).

A potential ibosome-binding site (GGAGA, +37 to +41) was identified $10 \mathrm{bp}$ upstream of the ATG initiation codon of the $p f l$ gene. In addition, potential -35 and -10 promoter regions (TTGGGA and TAAACT, -36 to -31 and -12 to -7 , respectively) were found. The structure of these promoter regions suggests that the expression of $p f l$ in $S$. bovis requires a sigma factor analogus to E. coli $\sigma^{70}$.

Primer extension analysis revealed that only one tran-

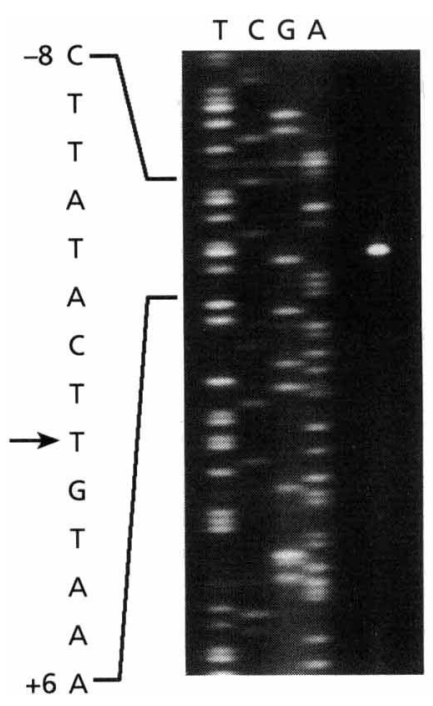

Fig. 3. Primer extension analysis of the $S$. bovis pfl gene. Primer extension was carried out with primer pfl-EX on $S$. bovis total RNA. A sequencing ladder was run with the same primer and is shown on the left. The transcriptional start site is indicated with an arrow beside the sequence.

scriptional start site existed $50 \mathrm{bp}$ upstream of the $p f l$ start codon (Figs 1 and 3). This is in contrast to E. coli, in which seven promoter regions have been implicated in the regulation and expression of $p f l$ (Sawers, 1993). An inverted repeat sequence characteristic of transcriptional terminators was detected between bases +2385 and +2416 , situated $10 \mathrm{bp}$ downstream of the termination codon of $S$. bovis $p f l$. The formation of a stem-loop structure in this region of the mRNA could be presumed by a free-energy change of $-8 \cdot 1 \mathrm{kcal} \mathrm{mol}^{-1}$. These results suggest that the $p f l$ gene from $S$. bovis is monocistronic.

\section{Transcription of the S. bovis pfl and Idh genes}

\section{Batch culture experiment}

S. bovis was grown in batch culture, maintaining the $\mathrm{pH}$ at approximately 6.9. Cell samples were taken at $2 \mathrm{~h}$ (mid-exponential phase), $5 \mathrm{~h}$ (late-exponential phase) and $6 \mathrm{~h}$ (just before the cessation of growth) after inoculation. Formate production per unit fermented glucose increased as the growth phase changed, from 2-6h (Table 1). Parallel with formate production, Pf activity per unit cellular nitrogen, which was considered to represent the cellular content of Pfl, increased with time. This result was in contrast to the previous observation that lactate production per unit glucose fermented and Ldh activity per unit cellular nitrogen decreased as the growth phase changed during the later stages of growth (Asanuma et al., 1997).

Northern-blot analysis indicated that a single transcript hybridizing with the $p f l$ probe was present in cells at any growth phase, which was estimated to be approximately 
Table 1. The change in formate production, Pfl activity and the relative amounts of $p f I$ mRNA at three growth stages in the batch culture of $S$. bovis

Values are presented as the mean $\pm \mathrm{SE}(n=3)$. Values within columns with no common superscript letters differ significantly $(P<0 \cdot 05, n=3)$.

\begin{tabular}{|lccc|}
\hline $\begin{array}{l}\text { Time } \\
(\mathbf{h})\end{array}$ & $\begin{array}{c}\text { Formate } \\
\text { produced }^{*}\end{array}$ & $\begin{array}{c}\text { Pfl } \\
\text { activity } \dagger\end{array}$ & $\begin{array}{c}\text { Relative amount } \\
\text { of } \boldsymbol{p} f \text { mRNA } \neq\end{array}$ \\
\hline 2 & $36 \pm 7^{\mathrm{c}}$ & $0 \cdot 9 \pm 0 \cdot 1^{\mathrm{c}}$ & $1 \cdot 0 \pm 0 \cdot 1^{\mathrm{c}}$ \\
5 & $78 \pm 6^{\mathrm{b}}$ & $2 \cdot 0 \pm 0 \cdot 3^{\mathrm{b}}$ & $1 \cdot 8 \pm 0 \cdot 2^{\mathrm{b}}$ \\
6 & $124 \pm 10^{\mathrm{a}}$ & $4 \cdot 4 \pm 0 \cdot 3^{\mathrm{a}}$ & $3 \cdot 4 \pm 0 \cdot 3^{\mathrm{a}}$ \\
\hline
\end{tabular}

* mol (100 mol glucose fermented $)^{-1}$. The amounts produced during $0-2,2-5$ and $5-6 \mathrm{~h}$ are shown.

$\dagger \mu \mathrm{mol}$ NADH oxidized $\min ^{-1}(10 \mu \mathrm{g} \text { cellular nitrogen })^{-1}$.

‡The bands shown in Fig. 4, separated from $10 \mu \mathrm{g}$ total RNA, were analysed by using a Fluor-S Multi Imager and are expressed as relative values.

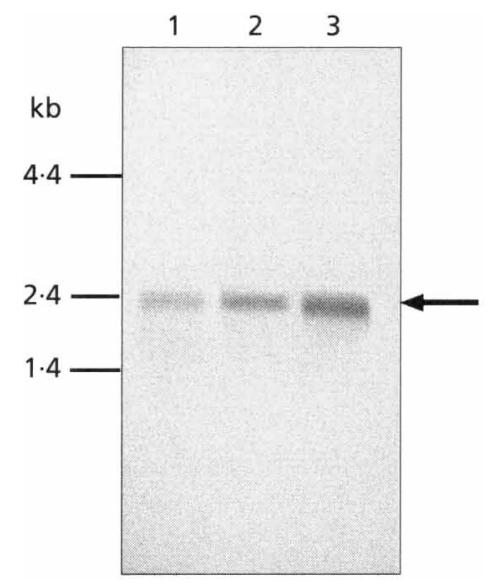

Fig. 4. The levels of pfl mRNA in $S$. bovis cells at three growth stages in batch culture. Cells were grown for $2 \mathrm{~h}$ (lane 1), $5 \mathrm{~h}$ (lane 2) or $6 \mathrm{~h}$ (lane 3). The arrow indicates the $2.3 \mathrm{~kb}$ pfl transcript.

$2.3 \mathrm{~kb}$ (Fig. 4). This result agreed with the nucleotide sequence analysis, suggesting that $S$. bovis $p f l$ has a monocistronic mode of transcription. In addition, primer extension analysis with the pfl-EX primer showed that the transcriptional start site did not change with growth stage (data not shown).

As shown in Table 1, the level of $p f$ mRNA increased during the late stages of growth. This result was in agreement with results showing that formate produced per unit glucose fermented and the content of $\mathrm{Pfl}$ increased with time (Table 1), and was in contrast to previous results showing that the level of $l d b$ mRNA decreased during the late stages of growth (Asanuma et al., 1997).

\section{Continuous culture experiment}

When $S$. bovis was grown in batch culture, excess glucose was initially present and the glucose concentration decreased as cells grew. The growth rate was considered to depend upon the availability of glucose. To examine whether the transcription of the $p f l$ and $l d h$ genes is regulated by growth rate or the abundance of glucose in cells, glucose-limited and ammonia-limited continuous culture was conducted.

As shown in Table 2, when S. bovis was grown at $\mathrm{pH} 6.9$ under glucose limitation, little glucose $(<0.1 \mathrm{mM})$ was present irrespective of dilution rate. The levels of ammonia were high $(23-25 \mathrm{mM})$, indicating that virtually all the glucose introduced into the fermenters was consumed immediately and the growth rate was dependent on the rate of glucose supply. However, under ammonia limitation, approximately $7 \mathrm{mM}$ glucose remained in the fermenters, indicating that excess glucose was supplied to the cells. A small amount of ammonia (approx. $0 \cdot 1 \mathrm{mM}$ ) remained in the fermenters, but this concentration of ammonia was probably too low for optimal growth. When the ammonia concentration in the reservoir was doubled, the cell density $\left(\mathrm{OD}_{600}\right)$ increased approximately twofold, indicating that the rate of ammonia supply limited the growth rate under ammonia-limiting conditions.

The percentage of lactate produced was greater under ammonia limitation than glucose limitation, at either a $\mathrm{D}$ of $0 \cdot 1$ or 0.6 (Table 2), suggesting that excess glucose increased lactate production. This is contrary to the formate production, which was lower under the ammonia limitation than glucose limitation. The Ldh activity per unit cellular nitrogen, which was considered to reflect the amount of Ldh per cell mass, parallelled the amount and percentage of lactate produced. Similarly, Pfl activity parallelled formate production.

When intracellular Ldh increased, Pfl decreased, indicating that the regulation of Ldh synthesis was in the opposite direction to Pfl synthesis. This result may be explained as follows. When intracellular glucose was abundant, glucose must have been fermentated to lactate with a small amount of ATP regenerated; under glucoselimited conditions cells needed to obtain a larger amount of ATP by fermenting glucose to acetate, ethanol and formate. Therefore, it is possible that a high ATP concentration or a high value of adenylate energy charge enhances Ldh synthesis and reduces Pfl synthesis. Another explanation may be that the intracellular pool of the intermediate products of glucose fermentation, fructose-1,6-diphosphate and triose phosphates, which affect the activity of Ldh (Asanuma et al., 1997) and Pfl (unpublished observation) respectively, may also affect Ldh and Pfl synthesis.

In both glucose- and ammonia-limited cultures, the percentage of lactate and Ldh activity were increased when $\mathrm{D}$ was increased (Table 2). Inversely, the percentage of formate and Pfl activity were decreased as D was increased. This suggested that growth rate per se 
Table 2. Effect of the abundance of glucose, $\mathrm{D}$ and $\mathrm{pH}$ on lactate and formate production, Ldh and Pfl activity, and the relative amounts of $/ d h$ and $p f I$ mRNAs in $S$. bovis grown in continuous culture

Data from the last day of the culture, in duplicate, from two sets of cultures $(n=4)$. Figures in parentheses indicate percentages in lactate plus formate. Values within columns with no common superscript letters differ significantly $(P<0.05)$.

\begin{tabular}{|c|c|c|c|c|c|c|c|c|c|c|c|}
\hline \multirow[t]{2}{*}{ Culture } & \multirow[t]{2}{*}{$D\left(h^{-1}\right)$} & \multirow[t]{2}{*}{$\mathrm{pH}$} & \multicolumn{2}{|c|}{ Glucose } & \multirow{2}{*}{$\begin{array}{l}\text { Ammonia } \\
\text { level (mM) }\end{array}$} & \multirow{2}{*}{$\begin{array}{c}\text { Lactate } \\
\text { produced } \\
\left(\text { mmol l}^{-1}\right)\end{array}$} & \multirow{2}{*}{$\begin{array}{c}\text { Formate } \\
\text { produced } \\
\left\langle\text { mmol l}^{-1}\right)\end{array}$} & \multirow{2}{*}{$\begin{array}{c}\text { Ldh } \\
\text { activity }\end{array}$} & \multirow{2}{*}{$\begin{array}{c}\text { Relative } \\
\text { amount of } \\
\text { ldh mRNA } \dagger\end{array}$} & \multirow{2}{*}{$\begin{array}{c}\text { Pfl } \\
\text { activity* }\end{array}$} & \multirow{2}{*}{$\begin{array}{c}\text { Relative } \\
\text { amount of } \\
p f l \text { mRNA }\end{array}$} \\
\hline & & & $\begin{array}{l}\text { Level } \\
(\mathrm{mM})\end{array}$ & $\begin{array}{l}\text { Consumed } \\
\left(\mathrm{mmol} \mathrm{1}^{-1}\right)\end{array}$ & & & & & & & \\
\hline Glucose limited & $0-1$ & 6.9 & $<0.1$ & $16 \cdot 5$ & 23 & $2 \cdot 7^{\mathrm{d}}(8 \cdot 8)$ & $28 \cdot 0^{a}(91 \cdot 2)$ & $28^{d}$ & $1.00^{\mathrm{d}}$ & $9 \cdot 4^{\mathrm{a}}$ & $1.00^{\mathrm{a}}$ \\
\hline Ammonia limited & $0 \cdot 1$ & 6.9 & $7 \cdot 0$ & $20 \cdot 8$ & $0 \cdot 1$ & $11 \cdot 4^{\mathrm{c}}(25 \cdot 2)$ & $27 \cdot 6^{\mathrm{a}}(74 \cdot 8)$ & $90^{\circ}$ & $1 \cdot 60^{\circ}$ & $5 \cdot 3^{\mathrm{b}}$ & $0.88^{\mathrm{b}}$ \\
\hline Glucose limited & 0.6 & $6 \cdot 9$ & $<0 \cdot 1$ & $16 \cdot 5$ & 24 & $12 \cdot 2^{\circ}(38 \cdot 4)$ & $19 \cdot 6^{\mathrm{b}}(61 \cdot 6)$ & $104^{c}$ & $1.64^{\circ}$ & $2 \cdot 7^{e}$ & $0.66^{\circ}$ \\
\hline Ammonia limited & 0.6 & 6.9 & 7.5 & $20-3$ & 0.1 & $20 \cdot 4^{b}(45 \cdot 2)$ & $20 \cdot 0^{\mathrm{b}}(54 \cdot 8)$ & $139^{h}$ & $2 \cdot 50^{\mathrm{b}}$ & $2 \cdot 5^{\mathrm{e}}$ & $0.60^{\mathrm{c}}$ \\
\hline Glucose limited & 0.1 & $4 \cdot 5$ & $<0 \cdot 1$ & 16.5 & 25 & $23 \cdot 0^{\mathrm{b}}(73 \cdot 0\rangle$ & $8 \cdot 5^{\circ}\langle 27 \cdot 0\rangle$ & $250^{\mathrm{a}}$ & $3 \cdot 40^{\mathrm{a}}$ & $<1 \cdot 0^{d}$ & $0.42^{\mathrm{d}}$ \\
\hline Ammonia limited & $0 \cdot 1$ & $4 \cdot 5$ & 8.8 & $18 \cdot 9$ & $0 \cdot 1$ & $28 \cdot 5^{a}(75 \cdot 4)$ & $9 \cdot 0^{\circ}(24 \cdot 6)$ & $263^{\mathrm{a}}$ & $3 \cdot 68^{\mathrm{a}}$ & $<1 \cdot 0^{\mathrm{d}}$ & $0.36^{a}$ \\
\hline
\end{tabular}

* $\mu$ mol NADH oxidized $\min ^{-1}(10 \mu \text { g cellular nitrogen })^{-1}$.

†Data were obtained from the bands as indicated in Table 1.

also affected the fermentation pathway downstream of pyruvate. Why Ldh and Pfl synthesis are affected by growth rate is inexplicable at present. The extent of the glucose-excess effect on Ldh synthesis was smaller at a D of 0.6 than $0 \cdot 1$, suggesting that lactate production had already been enhanced at the higher $\mathrm{D}$.

Northern-blot analysis showed that a single $1.0 \mathrm{~kb}$ transcript that hybridized with the $l d h$ probe was present (data not shown). The relative amounts of $l d h$ mRNA are summarized in Table 2 . The amount of $l d h$ mRNA increased when D, i.e. growth rate, increased at $\mathrm{pH} 6.9$ in both the glucose- and ammonia-limited cultures. At the same $\mathrm{D}$, the level of $l d h$ mRNA was higher in the ammonia-limited than the glucose-limited culture. Cells having a larger amount of Ldh also had a larger amount of $l d h$ mRNA (Table 2). However, the magnitude of the change in $l d h$ mRNA content was smaller than that in Ldh content. It is not surprising that the amount of mRNA was not exactly proportional to the amount of protein translated from it. Possibly, the turnover rate of mRNA is much higher than that of protein, and as a result the protein accumulates in cells. Regulation of Ldh synthesis at the translational level may also be possible, but the present results appeared to indicate that Ldh synthesis was at least in part regulated at the transcriptional level, responding to both growth rate and the abundance of glucose.

Northern-blot analysis with the $p f l$ probe showed a single $2 \cdot 3 \mathrm{~kb}$ transcript (data not shown). As shown in Table 2, the amount of $p f l \mathrm{mRNA}$ decreased when $\mathrm{D}$ was increased at $\mathrm{pH} 6.9$ in both glucose- and ammonialimited cultures. At the same D, the level of $p f l$ mRNA tended to be slightly higher in the glucose-limited than the ammonia-limited culture. The Pfl content in the cells was consistent with the result of the Northern-blot analysis.

When glucose-limited continuous culture was performed at $\mathrm{pH} 4.5$, the percentage of lactate and the content of Ldh greatly increased, compared to the values for $\mathrm{pH} 6.9$ (Table 2). Similar to the observations described above, the ammonia-limited culture did not have further effect on the percentage of lactate and Ldh content.

Northern-blot analysis indicated that the cells grown at $\mathrm{pH} 4.5$ possessed a larger amount of $l d h$ mRNA than cells grown at $\mathrm{pH} 6.9$ in both glucose- and ammonialimited cultures (Table 2). There was little difference in the amount of $l d h$ mRNA between the glucose- and ammonia-limited cultures. These results confirmed the observations obtained in batch culture (Asanuma et al., 1997). On the other hand, cells grown at $\mathrm{pH} 4.5$ possessed a smaller amount of $p f l$ mRNA than cells grown at $\mathrm{pH} 6.9$ in both glucose- and ammonia-limited cultures (Table 2). S. bovis cells grown at $\mathrm{pH} 4.5$ contained a much smaller amount of $\mathrm{Pfl}$ than cells grown at pH 6.9 (Table 2), apparently suggesting that $\mathrm{Pfl}$ synthesis is suppressed at low $\mathrm{pH}$. These results suggest that $S$. bovis regulates $\mathrm{Ldh}$ and $\mathrm{Pfl}$ synthesis at the transcriptional level in response to a change in $\mathrm{pH}$, probably internal pH (Russell \& Hino, 1985; Russell, 1991).

Collectively, including all the data in Table 2, cells having a larger amount of Ldh and Pfl generally had a larger amount of $l d h$ mRNA and $p f l$ mRNA, respectively. These results show that the synthesis of $\mathrm{Ldh}$ and $\mathrm{Pfl}$ is regulated at the transcriptional level in response to growth conditions. In addition to allosteric regulation (see above), transcriptional regulation appears to be important.

As previously described for Ldh (Asanuma et al., 1997), the level of mRNA mainly reflects the rate of transcription, but it is also possible that the concentration of mRNA is affected by the rate of its degradation. The problem as to the life of mRNA remains to be solved. The mechanism of regulation at the transcriptional level, as well as the translational level, also remains to be clarified. 


\section{ACKNOWLEDGEMENTS}

This work was supported in part by Research Fellowships of the Japan Society for the Promotion of Science for Young Scientists (No. 8156) and Grants-in-Aid for Scientific Research from the Japanese Ministry of Education, Science, Sports and Culture.

\section{REFERENCES}

Arnau, J., Jorgensen, F., Madsen, S. M., Vrang, A. \& Israelsen, H. (1997). Cloning, expression, and characterization of the Lactococcus lactis pfl gene, encoding pyruvate formate-lyase. $J$ Bacteriol 179, 5884-5891.

Asanuma, N. \& Hino, T. (1997). Tolerance to low $\mathrm{pH}$ and lactate production in rumen bacteria. Anim Sci Technol 68, 367-376.

Asanuma, N., Iwamoto, M. \& Hino, T. (1997). Regulation of lactate dehydrogenase synthesis in a ruminal bacterium, Streptococcus bovis. J Gen Appl Microbiol 43, 325-331.

Asanuma, N., Iwamoto, M. \& Hino, T. (1998). Formate metabolism by ruminal microorganisms in relation to methanogenesis. Anim Sci Technol 69, 576-584.

Chaney, A. L. \& Marbach, E. P. (1962). Modified reagents for the determination of urea and ammonia. Clin Chem 8, 130-132.

Conway, E. J. \& Byrne, A. (1933). An absorption apparatus for the micro-determination of certain volatile substances. I. The microdetermination of ammonia. Biochem J 27, 419-429.

Fordyce, A. M., Crow, V. L. \& Thomas, T. D. (1984). Regulation of product formation during glucose or lactate limitation in nongrowing cells of Streptococcus lactis. Appl Environ Microbiol 48, 332-337.

Hino, T. \& Hamano, S. (1993). Effects of readily fermentable carbohydrate on fiber digestion by rumen microbes in continuous culture. Anim Sci Technol 64, 1070-1078.

Hino, T. \& Miwa, T. (1996). An improved apparatus for the continuous culture of rumen bacteria that require particularly strict anaerobiosis. Bull Fac Agric Meiji Univ 107, 59-64.

Hino, T., Mukunoki, H., Imanishi, K. \& Miyazaki, K. (1992). Necessity of ready electron disposal and interspecies hydrogen transfer for the utilization of ethanol by rumen bacteria. AsianAustralas J Anim Sci 5, 511-517.

Hino, T., Sugiyama, M. \& Okumura, K. (1993). Maintenance of protozoa and methanogens, and fiber digestion in rumensimulating continuous culture. J Gen Appl Microbiol 39, 35-45.

Hino, T., Shimada, K. \& Maruyama, T. (1994). Substrate preference in a strain of Megasphaera elsdenii, a ruminal bacterium, and its implications in propionate production and growth competition. Appl Environ Microbiol 60, 1827-1831.

Hungate, R. E. (1966). The Rumen and its Microbes, pp. 60-64. New York: Academic Press.

Kessler, D. \& Knappe, J. (1996). Anaerobic dissimilation of pyruvate. In Escherichia coli and Salmonella: Cellular and Molecular Biology, 2nd edn, vol. 1, pp. 199-205. Edited by F. C. Neidhardt and others. Washington, DC: American Society for Microbiology.

Knappe, J. \& Blaschkowski, H. P. (1975). Pyruvate formate-lyase from Escherichia coli and its activation system. Methods Enzymol 41, 508-518.

Knappe, J., Neugebauer, F., Blaschkowski, H. P. \& Ganzler, M. (1984). Post-translational activation introduces a free radical into pyruvate formate-lyase. Proc Natl Acad Sci USA 81, 1332-1335.

Lindmark, D. G., Paolella, P. \& Wood, N. P. (1969). The pyruvate formate-lyase system of Streptococcus faecalis: purification of the formate-pyruvate exchange enzyme. J Biol Chem 244, 3606-3612.

McCormick, N. G., Ordal, E. J. \& Whiteley, H. R. (1962a). Degradation of pyruvate by Micrococcus lactilyticus. I. General properties of the formate-exchange reaction. J Bacteriol $\mathbf{8 3}$, 887-898.

McCormick, N. G., Ordal, E. J. \& Whiteley, H. R. (1962b). Degradation of pyruvate by Micrococcus lactilyticus. II. Studies of cofactors in the formate-exchange reaction. J Bacteriol 83, 899-906.

Marounek, M. \& Bartos, S. (1987). Interactions between rumen amylolytic and lactate-utilizing bacteria in growth on starch. J Appl Bacteriol 63, 233-238.

Parast, C. V., Wong, K. K., Lewisch, S. A. \& Kozarich, J. W. (1995). Hydrogen exchange of the glycyl radical of pyruvate formatelyase is catalyzed by cysteine 419. Biochemistry 34, 2393-2399.

Russell, J. B. (1991). Intracellular $\mathrm{pH}$ of acid-tolerant ruminal bacteria. Appl Environ Microbiol 57, 3383-3384.

Russell, J. B. \& Hino, T. (1985). Regulation of lactate production in Streptococcus bovis; a spiraling effect that contributes to rumen acidosis. J Dairy Sci 68, 1712-1721.

Sawers, G. (1993). Specific transcriptional requirements for positive regulation of the anaerobically inducible $p f l$ operon by ArcA and FNR. Mol Microbiol 10, 737-747.

Snedecor, G. W. \& Cochran, W. G. (1967). Statistical Methods, 5th edn. Ames: Iowa State University Press.

Thakahashi, S., Abbe, K. \& Yamada, T. (1982). Purification of pyruvate formate-lyase from Streptococcus mutans and its regulatory properties. J Bacteriol 149, 1034-1040.

Thauer, R. K., Kirschniawy, F. H. \& Jungermann, K. A. (1972). Properties and function of the pyruvate formate-lyase reaction in clostridiae. Eur J Biochem 27, 282-290.

Thomas, T. D., Turnere, K. W. \& Crow, V. L. (1980). Galactose fermentation by Streptococcus lactis and Streptococcus cremoris: pathways, products, and regulation. J Bacteriol 144, 672-682.

Urking, V., Neugebauer, F. A. \& Knappe, J. (1989). The free radical of pyruvate formate-lyase: characterization by EPR spectroscopy and involvement in catalysis as studied with the substrate analogue hypophosphite. Eur J Biochem 184, 723-728.

Vetter, H., Jr \& Knappe, J. (1971). Flavodoxin and ferredoxin of Escherichia coli. Hoppe-Seyler's Z Physiol Chem 352, 433-446.

Wagner, A., Frey, M., Neugebauer, F., Schafer, W. \& Knappe, J. (1992). The free radical in pyruvate formate-lyase is located on glycine-734. Proc Natl Acad Sci USA 89, 996-1000.

Whatley, F. R. \& Arnon, D. I. (1963). Photosynthetic phosphorylation in plants. Methods Enzymol 6, 308-313.

Wong, K. K., Murray, B. W., Lewisch, S. A., Baxter, M. K., Ridky, T. W., Ulissi-DeMario, L. \& Kozarich, J. W. (1993). Molecular properties of pyruvate formate-lyase activating enzyme. Biochemistry 32, 14102-14110.

Wood, N. P. \& Jungermann, K. (1972). Inactivation of the pyruvate formate-lyase of Clostridium butyricum. FEBS Lett 27, 49-52.

Yamamoto, Y., Sato, Y., Takahashi-Abbe, S., Abbe, K., Yamada, T. \& Kizaki, H. (1996). Cloning and sequence analysis of the $p f l$ gene encoding pyruvate formate-lyase from Streptococcus mutans. Infect Immun 64, 385-391.

Received 3 July 1998; revised 8 September 1998; accepted 7 October 1998. 